\title{
The relationship between the compressive strength and ultrasonic pulse velocity concrete with fibers exposed to high temperatures
}

\author{
Belaribi Hassiba ${ }^{1}$, Mellas Mekki ${ }^{2}$, Rahmani Farid ${ }^{3}$ \\ ${ }^{1}$ Laboratoire de génie civil, Département de Génie civil et hydraulique, Université Mohammed Khider Biskra 07000 \\ ${ }^{2}$ Laboratoire de génie civil, Département de Génie civil et hydraulique, Université Mohammed Khider Biskra 07000 \\ ${ }^{3}$ Département de Mécanique, Université Mohammed Khider Biskra 07000 \\ Farsoul@yahoo.fr
}

\begin{abstract}
The paper analyses the effects of high temperatures on the concrete residual strength using ultrasonic velocity (UPV). An experimental investigation was conducted to study the relationship between UPV residual data and compressive strength of concrete with different mixture proportions, cubic specimens with water-cement ratio of 0.35 . They were heated in an electric furnace at temperatures ranging from $200^{\circ} \mathrm{C}$ to $600^{\circ} \mathrm{C}$. In this experiment a comparison was made between the four groups which include two types of fibers steel 0,19\%, 0,25\% and 0,5\%, polypropylene: $0,05 \%, 0,11 \% 0,16 \%$ by volume. Cube specimens were tested in order to determine ultrasonic velocity. The compressive strength was tested too. According to the results, relations were established between ultrasonic velocity in the specimens and the compressive strength at different temperature and the range of the velocity of the waves were also determined for this kind of concrete. Result of the test showed that UPV test can be successfully used in order to verify the consistency of structures damaged by fire.
\end{abstract}

Keywords: Ultrasounds; non-destructive testing; concrete, fibers, temperature, steel, polypropylene.

Received: 01/12/2017 - Accepted: 11/04/2018

\section{Introduction}

Concrete is a building material that finds its field of use virtually in all areas of civil engineering. That is, it includes buildings, tunnels, oil platforms, nuclear power plants and other several structures that may be exposed to high temperatures or fire. The effect of high temperatures study on concrete structures started in 1920 However, in the mid-1990s, a new interest in evaluating the performance of the concrete when it was subjected to extreme temperatures was carried out in particular after fires in different tunnels [1].

When concrete exposed to high temperatures, the chemical composition and physical structure change considerably, resulting in a significant reduction of the mechanical properties, such as strength, modulus of elasticity and volume stability[2].One of the successful techniques for detection of chemical and physical changes and damage in concrete is the use of nondestructive testing methods, The ultrasonic method is one of the nondestructive testing techniques and is frequently adopted for evaluating the quality in situ concrete structures[3,4, 5,6]. For concrete with a density of approximately $2400 \mathrm{~kg} / \mathrm{m} 3$ are given as excellent, good, doubtful, poor and very poor for $4500 \mathrm{~m} / \mathrm{s}$ and above, 3500-4500, 3000-3500, 2000-3000 and $2000 \mathrm{~m} / \mathrm{s}$ and below UPV values, respectively According to the classification criterion for concrete based on ultrasonic pulse measurements by Whitehurst [7]. Several experimental studies had been carried out to investigate how the pulse velocity was affected by the damage of concrete caused by various high temperatures and have been made to develop the relation between the ultrasonic pulse velocity and the compressive strength at high temperature. The following equations are the most important ones established by various scientists given in table 1: 


\begin{tabular}{|c|c|c|c|}
\hline Formula & R2 & The scientist & Year \\
\hline$(\mathrm{ft} / \mathrm{fo})=-0.07+3.29(\mathrm{Vt} / \mathrm{Vo})-2.42(\mathrm{Vt} / \mathrm{Vo}) 2$ & 0.98 & \multirow{2}{*}{ H.W.CHUNG [8] } & \multirow{2}{*}{1985} \\
\hline $\mathrm{ft} / \mathrm{fo})=-0.08+2.15\{\mathrm{Vt} / \mathrm{Vo})-1.32(\mathrm{~V} / \mathrm{Vo}) 2$ & 0.91 & & \\
\hline $\mathrm{fc}=17,244 \mathrm{e} 0,2997 \mathrm{v}$ & 0,8354 & Suhaendi SL, Horiguchi T [9] & 2006 \\
\hline $\begin{array}{ll}\mathrm{Y}=37,43 \mathrm{x}+3190 & \text { At } 28 \text { Days } \\
\mathrm{Y}=40,11 \mathrm{x}+3093 & \text { At } 90 \text { Days }\end{array}$ & $\begin{array}{l}0,901 \\
0,918\end{array}$ & Prashant Y.Pawade [10] & 2011 \\
\hline $\begin{array}{c}\mathrm{fc}=14,804 \mathrm{e} 0,0002 \mathrm{UPV} \text { mesure methode direct } \\
\mathrm{fc}=7,5391 \mathrm{e} 0,0003 \mathrm{UPV} \text { mesure methode semi direct } \\
\mathrm{fc}=6,5583 \mathrm{e} 0,0004 \mathrm{UPV} \text { mesure methode indirect }\end{array}$ & $\begin{array}{l}0,63 \\
0,70 \\
0,68\end{array}$ & K. PRASOPCHAICHANA [11] & 2012 \\
\hline $\begin{array}{c}\mathrm{fc}=44,86 \ln \mathrm{Vt}+25,15 \text { for Ordinary concrete } \\
\mathrm{fc}=22,09 \ln \mathrm{Vt}+15,81 \text { for High performance concrete }\end{array}$ & $\begin{array}{l}0,949 \\
0,961 \\
\end{array}$ & $\begin{array}{c}\text { Izabela Hager and Hélène Carré } \\
{[12]}\end{array}$ & 2012 \\
\hline $\mathrm{fc}=19,034 \mathrm{~V}-54,026$ & 0,987 & Olowofoyeku Adeoye M., [13] & 2013 \\
\hline
\end{tabular}

The article examines the residual compressive strength and ultrasonic pulse velocity of concrete that has been cured with water after exposure to elevated temperatures. The relationship between the residual strength ratio and the residual UPV ratio was developed. Cubic specimens were made of concrete with water-cement ratios of 0.35 after 56 days, the samples were heated in an electric furnace at temperatures ranging from 400 to $600^{\circ} \mathrm{C}$. The speed of the ultrasonic pulse and the compressive strength of each test piece after curing of fire are measured immediately after 24 hours of cooling. The results obtained indicate that the application of UPV has demonstrated to be a trustworthy analysis, being able to prove the effectiveness of its use on fire-damaged concrete structures.

\section{Experimental study}

The materials used for the different concretes are: -The cement used to make the concrete was the CPJ CEM II/A 42,5. The cement density was $3 \mathrm{~kg} / \mathrm{dm} 3$ and the compressive strength measured at 28 days was $>40$ $\mathrm{MPa}$

-Aggregates:

Crushed gravel class $8 / 15 \mathrm{~mm}$, density was $2.61 \mathrm{~kg} / \mathrm{dm} 3$ A crushed gravel class $3 / 8 \mathrm{~mm}$, density was $2.63 \mathrm{~kg} / \mathrm{dm} 3$ Sand class $0 / 5 \mathrm{~mm}$, density was $2.57 \mathrm{~kg} / \mathrm{dm} 3$

- water-reducing superplasticizer named Sika Viscocrete Tempo 12.

-Steel fibers:The fibers used are SIKA FIBRE RL-45/50$\mathrm{BN}$ which are made from steel wire. They have a mechanical ink consisting of hooks to the end. They were cylindrical of $50 \mathrm{~mm}$ length with a diameter of $1.05 \mathrm{~mm}$. the tensile strength was $1000 \mathrm{Mpa}$ and Temperature de fusion are $1380^{\circ} \mathrm{C}$

-Polypropylene fibers: Polypropylene high tenacity fibers are used for reinforcement of concretes with length 12 $\mathrm{mm}$ and density was $0.91 \mathrm{~kg} / \mathrm{dm} 3$ andTemperature de fusion are between $160-170{ }^{\circ} \mathrm{C}$.

Tree groups of high strength concrete mixes were studied: The first group of concrete mixes without fibers (B), the second mixes with polypropylene fibers (BP), the third mixes with steel fibers (BM). All mixes have the same water/cement $(\mathrm{W} / \mathrm{C})$ ratio of 0.35 and the same paste volume. Three volume fractions of polypropylene fibers in the concrete were tested: $0.05,0.11 \%$ and $0.17 \%$ (Equivalent to $0.5,1$ and $1.5 \mathrm{~kg} / \mathrm{m}^{3}$ ). Three volume fractions of steel fibers were used: $0.19 \%, 0.25 \%$ and 0.5 (equivalent to 15 to 19.5 and $39 \mathrm{~kg} / \mathrm{m}^{3}$ ). Of cubic specimens $(10 \times 10 \times 10) \mathrm{cm}$ were manufactured and preserved in water until 28 days after unmolding. After that they were dried in the open air ( 28 days) before the heat treatment. Three cycles of heating - cooling from room temperature $\left(20^{\circ} \mathrm{C}\right)$ and up to bearing different temperatures: $200^{\circ} \mathrm{C}, 400^{\circ} \mathrm{C}$ and $600^{\circ} \mathrm{C}$ were applied to the specimens by means of an electric furnace. Each cycle consists of three phases. The first is a temperature rise at a ramp rate of $10^{\circ} \mathrm{C} / \mathrm{min}$. then constant temperature level in the oven for one hour. The mechanical properties of the specimens were determined before and after the heat treatment by conventional testing according to the standard NF EN 12390-3 [14] for the compressive strength. The mixture proportions of the different concretes are presented in Table 2.

Table 2Mix proportions

\begin{tabular}{|l|c|c|c|c|c|c|c|}
\hline Mixture & $\begin{array}{c}\text { without } \\
\text { fibers }\end{array}$ & \multicolumn{3}{r|}{ \% steel fibers } & \multicolumn{3}{c|}{ \% polypropylene fibers } \\
\hline$\%$ of fibers & 0 & 0.19 & 0.25 & 0.5 & 0.055 & 0.11 & 0.16 \\
\hline W/C & 0.35 & 0.35 & 0.35 & 0.35 & 0.35 & 0.35 & 0.35 \\
\hline Water Kg & 158 & 158 & 158 & 158 & 158 & 158 & 158 \\
\hline Cement Kg/m ${ }^{3}$ & 450 & 450 & 450 & 450 & 450 & 450 & 450 \\
\hline $\begin{array}{l}\text { Aggregates } \\
\text { sizes (mm) }\end{array}$ & & & & & & & \\
\hline $8 / 15 \mathrm{~mm} \mathrm{Kg} / \mathrm{m}^{3}$ & 182.91 & 181.91 & 180.91 & 180.91 & 180.66 & 180.26 & 179.16 \\
\hline $3 / 8 \mathrm{~mm} \mathrm{Kg} / \mathrm{m}^{3}$ & 1016.79 & 1001.79 & 1001.79 & 984.97 & 1016.29 & 1015.79 & 1015.29 \\
\hline $0 / 5 \mathrm{~mm} \mathrm{Kg} / \mathrm{m}^{3}$ & 585.44 & 585.44 & 581 & 580 & 585.44 & 585.44 & 585.44 \\
\hline $\begin{array}{l}\text { Superplasticizer } \\
\text { (\% in dry } \\
\text { extract) }\end{array}$ & 1.5 & 1.7 & 1.9 & 2 & 2 & 2.1 & 2.2 \\
\hline
\end{tabular}




\section{RESUlTS AND DISCUSSIONS}

The results obtained in this study were presented in figures1-6. They are evaluated and discussed below.

\section{III.1.1. The Effect of the Steel Fibers on the compressive Strength and UPV Influenced by Temperature}

For percentages of fibers $0.19 \%, 0.25 \%$ et $0.5 \%$ respectively, It is seen that at $200{ }^{\circ} \mathrm{C}$ the compressive strength decreased $14 \%, 15 \%$ and $3 \%$ compared to the room temperature strength. The reduction in compressive strength for samples heated to $400{ }^{\circ} \mathrm{C}$ was $25 \%$, to $33 \%$ compared to the room temperature strength. After heating to $600{ }^{\circ} \mathrm{C}$ the compressive strength decreased $38 \%$, to 44 $\%$ compared to the room temperature strength. Obviously, compressive strengths concrete deteriorates with the increasing in maximum heat temperature as shown in Figure 1.Similar behavior has already been observed in the literature $[15,16,17,18,19]$. The volume percentage has no efficacy after heating at $200^{\circ}$ which is confirmed by [9]. (The fiber percentage is less than $0.5 \%$ ).

It is known that concrete quality can be classified by UPV value: if the value is more than $4500 \mathrm{~m} / \mathrm{s}, 3500-$ $4500 \mathrm{~m} / \mathrm{s}, 3000-3500 \mathrm{~m} / \mathrm{s}, 2000-3000 \mathrm{~m} / \mathrm{s}$ and less than $2000 \mathrm{~m} / \mathrm{s}$, the concrete is classified as "excellent", "good", "doubtful", "poor" and "very poor", respectively[6]. By comparing the residual UPV at different heating temperatures; It is seen UPV measurements at $200{ }^{\circ} \mathrm{C}$ is $4696.67 \mathrm{~m} / \mathrm{s}, 4680 \mathrm{~m} / \mathrm{s}$ and $4633.33 \mathrm{~m} / \mathrm{s}$ for percentages of fibers $0,38 \%, 0,19 \%$ et $0.19 \%$ respectively the concrete is classified as excellent quality of concrete and at $400{ }^{\circ} \mathrm{C}$ The (UPV) measurement are $3873.33 \mathrm{~m} / \mathrm{s}$ for $0.5 \%$, percentage of steel fibers the results obtained are considered good interms of quality, the same remark for $0.25 \%$ were UPV are $3753.33 \mathrm{~m} / \mathrm{s}$ were are considered good et doubtful for $0.19 \%$ where the UPV are $3260 \mathrm{~m} / \mathrm{s}$ and from then temperature $600^{\circ}$ the pulse velocity decrease there is a very significant reduction $2943.33 \mathrm{~m} / \mathrm{s}, 2870 \mathrm{~m} / \mathrm{s}$ and $2416.67 \mathrm{~m} / \mathrm{s}$ are considered poor in-terms of quality..All specimens degraded from "excellent" to "good", to "doubtful", to "poor" respectively. The UPV values decreased for all mixture types after exposure to elevated temperatures as presented in figure2in accordance with other authors [5, 8, 9, 19,20,21 22,].

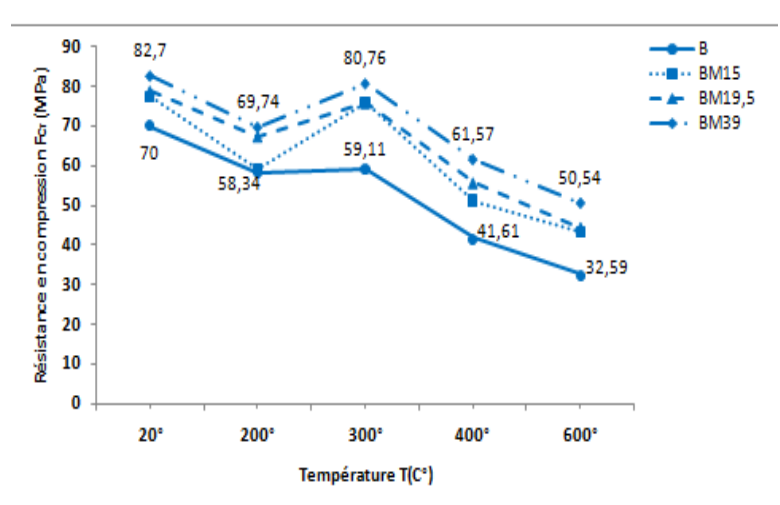

Fig. 1. Relationship between compressive strength and temperature for different percentage of steel fibers.

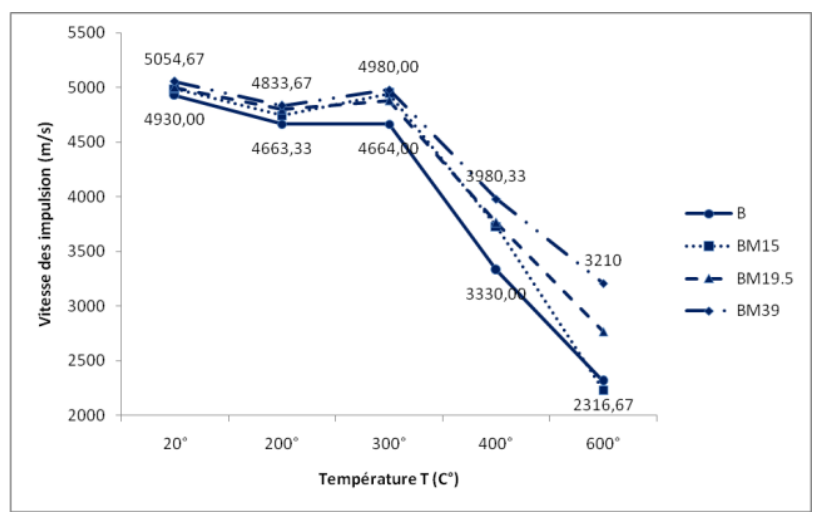

Fig. 2 The relationship between UPV $(\mathrm{m} / \mathrm{s})$ and temperature for different percentage of steel fibers

\section{III.1.2. The Effect of the Polypropylene Fibers on the Compressive Strength and UPV Influenced by Temperature}

For percentages of fibers polypropylene $0.16 \%, 0.11 \%$ and $0.05 \%$ respectively; It is seen that at $200{ }^{\circ} \mathrm{C}$ the compressive strength decreased $17.15 \%, 17.90 \%$ and $15.70 \%$ compared to the room temperature strength. The reduction in compressive strength for samples heated to $400{ }^{\circ} \mathrm{C}$ was $30.45 \%$ and $32.79 \%$ and $33.55 \%$ compared to the room temperature strength. After heating to $600{ }^{\circ} \mathrm{C}$ the compressive strength decreased $43.16 \%, 46.47 \%$ and $47.70 \%$ compared to the room temperature strength. Obviously, compressive strength concrete deteriorate with the increasing in maximum heat temperature as shown in figure 3 , A similar behavior has already been observed by other scientists like Xiao [23] and others[24, $25,26]$.

It is seen that UPV measurements at $200 \mathrm{c}^{\circ}$ is 4681,55 $\mathrm{m} / \mathrm{s}, 4653.33 \mathrm{~m} / \mathrm{s}$ and $4620 \mathrm{~m} / \mathrm{s}$ for percentages of fibers $0.17 \%, 0.11 \%$ and $0.05 \%$ respectively the concrete is classified as excellent quality of concrete; and at $400^{\circ} \mathrm{C}$ The UPV measurement are $3743.33 \mathrm{~m} / \mathrm{s}$ for $0.17 \%$, percentage of polypropylene fibers where the results obtained are considered excellent in-terms of quality, for the $0.11 \%$ and $0.05 \%$ UPV are $3393.33 \mathrm{~m} / \mathrm{s}$ and $2993.33 \mathrm{~m} / \mathrm{s}$ are considered good and from thence temperature $600^{\circ}$ the pulse velocity decrease there is a very significant reduction $2666.67 \mathrm{~m} / \mathrm{s}, 2593.33 \mathrm{~m} / \mathrm{s}$ 
and $2286.67 \mathrm{~m} / \mathrm{s}$ are considered poor in-terms of quality. The UPV values decreased for all mixture types after exposure to elevated temperatures as presented in figure 4accordance with works of $[5,8,9,19,20,2122$,$] .$

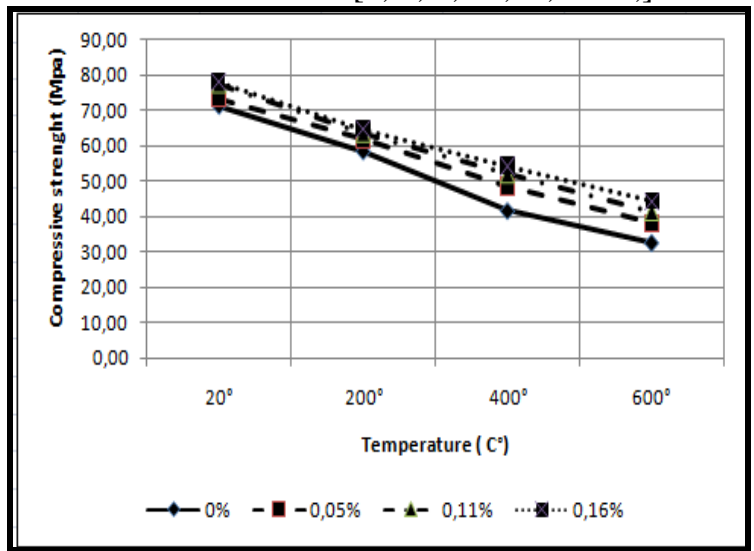

Fig. 3. The relationship between compressive strength and temperature for different percentage of polypropylene fibers.

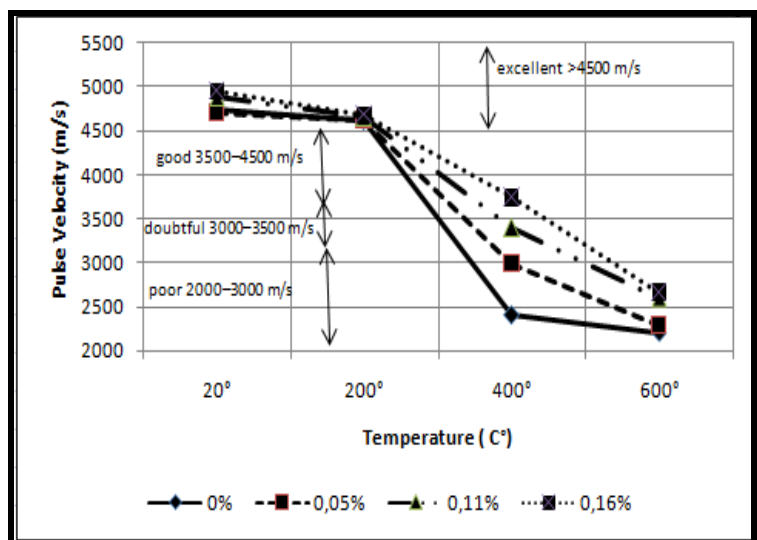

Fig.4. The relationship between UPV $(\mathrm{m} / \mathrm{s})$ et la temperature for different percentage of polypropylene fibers.

III.1.2. Relationship between ultrasonic pulse velocity UPV and Compressive Strength

Many scientists have studied how UPV can be correlated with concrete strength. According to previous research by [34] and [33], the compressive strength and ultrasonic pulse velocity UPV values are related by the following equation A (non-linear model is suggested)

$$
f_{c}=a e^{b \mathbf{v}}
$$

Where $\mathrm{Fc}$ is the compressive strength, $\mathrm{Vc}$ is the pulse velocity $(\mathrm{km} / \mathrm{s})$, $a$ and $b$ are empirical constants [33]

The following law relating compressive strength (f c in MPa) to UPV ( $\mathrm{Vc}$ in $\mathrm{m} / \mathrm{s}$ ) for concrete with steel fibers:

$$
\mathrm{Fc}=17,476 \mathrm{e}^{0,0003 \mathrm{~V}} \text { et } \mathrm{R}^{2}=0,6739
$$

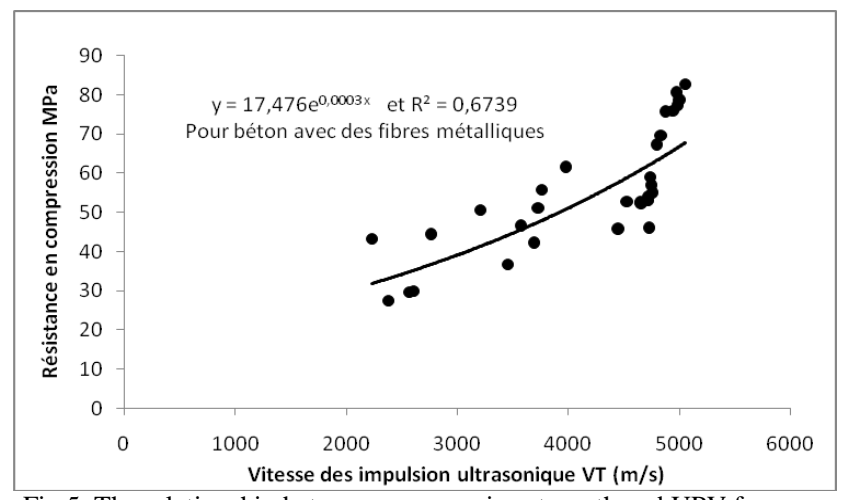

Fig.5. The relationship between compressive strength and UPV for concrete with steel fibers

The following law relating compressive strength (f c in $\mathrm{MPa}$ ) to UPV ( $\mathrm{Vc}$ in $\mathrm{m} / \mathrm{s}$ ) for concrete without fibers:

$$
\mathrm{Fc}=8,5773 \mathrm{e}^{0,0004 \mathrm{v}} \text { et } \mathrm{R}^{2}=0,8419
$$

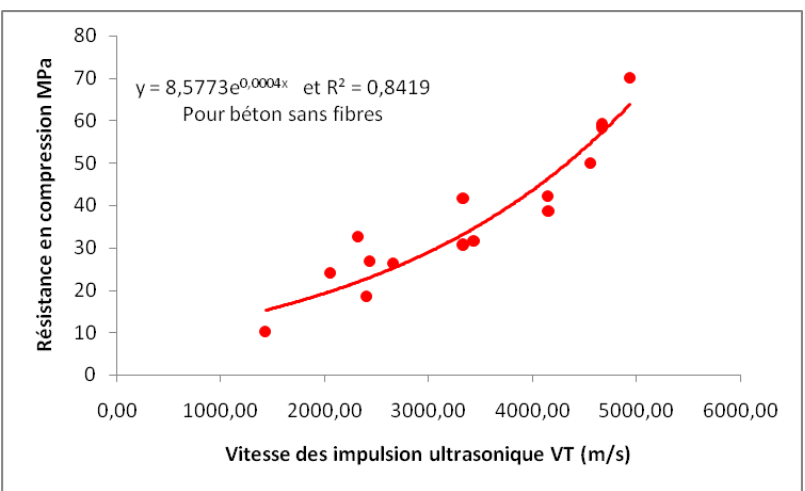

Fig.6. The relationship between compressive strength and UPV for concrete without fibers

The following law relating compressive strength (f c in $\mathrm{MPa}$ ) to UPV ( $\mathrm{Vc}$ in $\mathrm{m} / \mathrm{s}$ ) for concrete without fibers:

$$
\mathrm{Fc}=16,312 \mathrm{e}^{0,0003 \mathrm{v}} \text { et } \mathrm{R}^{2}=0,8713
$$

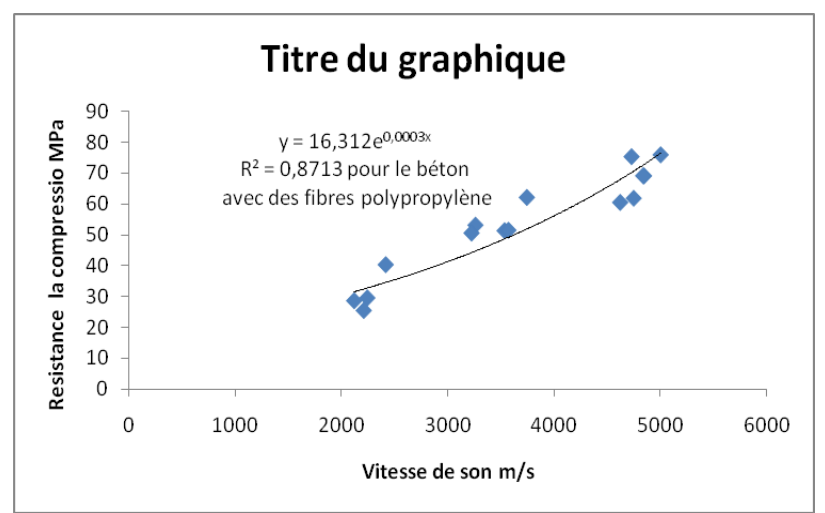

Fig.5. The relationship between compressive strength and UPV for concrete with polypropylene fibers 


\section{CONCLUSION}

Based on the experimental results were noticed:

- The compressive strength and the UPV ultrasonic speed deteriorate with increasing temperature whatever the nature of the fibers.

- Analysis of local materials shows that they meet the standards for the manufacture of quality concrete.

- The steel fibers improve the compressive strength of concretes for all heating-cooling cycles. It is concluded that the incorporation of this type of fiber is advantageous in concrete that has been exposed to elevated temperatures.

- The polypropylene fibers are generally no significant influence on the improvement of the resistance to the residual compression for the concrete after high temperature heating.

- The different grades of polypropylene and metal fibers do not change the kinetics of the compressive strength loss.

- The increase of percentage of the polypropylene fibers in the concrete polypropylene fibers and metal is an adverse effect on the compressive strength.

- The feature of concrete with the mixture of polypropylene fibers and metal is closer to the concrete with metal fibers.

-An exponential relationship between UPV and compressive strength for the different concrete mix has provided an adequate approximation for comparing them with $\mathrm{R}^{2}$ values in the range of $67-87 \%$

- The results indicate that the exponential relationship provides an adequate approximation for comparing the values UPV and compressive strength.

- The constant $b$ values in the range 0.0003 and 0.0004

- The ultrasound test is found to be an effective tool to assess the degree of damage in concrete structures exposed to high temperatures.

\section{References}

[1] Laboratoire Central des Ponts et Chaussées, Présentation des techniques de diagnostic de l'état d'un béton soumis a' un incendie. Report ME 62 (in French), 2005.

[2] L. d. Kirchhof, A. lorenzi, L. S Filho, Assessment of Concrete Residual Strength at High Temperatures using Ultrasonic Pulse Velocity .20 No.7 2015- The e-Journal of Nondestructive Testing - ISSN 1435-4934.

[3] M. Colombo, R. Felicetti, New NDT techniques for the assessment of fire-damaged concrete structures. Fire Saf J 42, 2007, pp 461-472.

[4] H.W Chung, KS Law, Assessing fire damage of concrete by the ultrasonic pulse technique. Cement, Concrete and Aggregates, 7, 1985, pp 84-88.

[5] L. Logothetis, C. Economou, The influence of high temperatures on calibration of non-destructive testing of concrete), 14(79)- 1979, Materiaux et Constructions.

[6] M. Y. L. Chew, The Assessment of Fire Damaged Concrete, Building and Environment, 28(1), 1993, pp $97-$ 10.
[7] E.A. Whitehurst, Soniscope tests concrete structures, J. Am. Concr. Inst. 47, 1951, pp 443 - 444.

[8] H.W.Chung (1985), Ultrasonic testing of concrete after exposure to high temperatures, MNDT international. vol 18. NO 5. 1985

[9] S. L. Suhaendi,T.Horiguch, Effect of short fibers on residual permeability and mechanical properties of hybrid fibre reinforced high strength concrete after heat exposition CemConcr Res 36, 2006, pp 1672-1678.

[10] P. Y. Pawade, Performance of steel fiber on standard strength concrete in compression, international journal of civil and str structural engineering Volume 2, No 2, 2011, ISSN 0976 - 4399.

[11] K. PRASOPCHAICHANA, Evaluating the Compressive Strength of Concrete Exposed to Elevated Temperatures Using Ultrasonic Pulse Velocity and Artificial Neural Networks, 6th European Workshop on Structural Health Monitoring - Poster 17

[12] I. Hager, H. Carré and K. Krzemień,Damage Assessment Of Concrete Subjected To High Temperature By Means Of The Ultrasonic Pulse Velocity - Upv Method Studies And ResearcheS - V.32, Graduate School in Concrete Structures - FratelliPesenti, Politecnico di Milano, Italy, 2013.

[13] O. deoye M, Domestication Of Pundit Non-Destructive Test Chart In Measuring Compressive Strength Of Normal Strength Concrete Subjected To Elevated Temperature ,Australian Journal of Basic and Applied Sciences, 7(1): 16, 2013 , ISSN 1991-8178

[14] NF EN 12390-3. Essai pour béton durci - Partie 3: Résistance à la compression des éprouvettes, Indice de classement: P 18-455, 2003.

[15] Y. F Chang; Y. H Chen, M. S Sheu, G.C Yao, Residual stress-strain relationship for concrete after exposure to high temperatures, Cement and Concretes Resarch 36 (10), 2006, pp 1999-2005.

[16] A. Lau, M. Anson, Effect of high temperatures on high performance steel fiber reinforced concrete. Cement Concrete Res; 2006, 36:1698-707.

[17] P. Pliya, A.L Beaucour, A. Noumowé, Strength and porosity of concrete incorporating polypropylene and steel fibres subjected to high temperature. In: 20th international conference on structural mechanics in reactor technology, Espoo, Finland, 2009, pp 9-14.

[18] C.S Poon, Z.H Shui, L. Lam, Compressive behavior of fiber reinforced highperformance concrete subjected to elevated temperatures. Cement Concrete Res, 34, 2004, pp 2215-22.

[19] S.K. Handoo, S. Agarwal, S.K. Agarwal, Physicochemical, mineralogical, and morphological characteristics of concrete exposed to elevated temperatures, Cement and Concrete Research 32, 2002, pp $1009-1018$.

[20] H. Yang, Y. Lin, C. Hsiao, J.Y Liu, Evaluating residual compressive strength of concrete at elevated temperatures using ultrasonic pulse velocity, Fire Safety Journal 44 , 2009, pp 121- 130 .

[21] Y. Lin, C. Hsiao, H. Yang, Y.F Lin, The effect of postfire-curing on strength-velocity relationship for nondestructive assessment of fire-damaged concrete strength, Fire Safety Journal 46, 2011, pp 178-185.

[22] Savva, P. Manita, K.K. Sideris, Influence of elevated temperatures on the mechanical properties of blended cement concretes prepared with limestone and siliceous aggregates, Cement Concr. Compos. 27, 2005, pp 239 248. 
[23] J. Xiao, H. Falkner, On residual strength of highperformance concrete with and without polypropylene fibres at elevates temperatures. Fire Safety, 41 2006, pp 115-21.

[24] M. Zeiml, D. Leithner, R. Lackner, H. Mang, How do polypropylene fibers improve the spalling behavior of insitu concrete? Cement Concrete Res. 2006.

[25] A. Noumowé, Mechanical properties and microstructure of high strength concrete containing polypropylene fibers exposed to temperatures up to $200^{\circ} \mathrm{C}$. Cement Concrete Res, 35, pp 2192-8.

[26] A. Behnood, M. Ghandehari, Comparison of compressive and splitting tensile strength of high-strength concrete with and without polypropylene fibers heated to high temperatures. Fire Safety J 2009.

[27] G.F Peng, W.W Yang, J. Zhao, Y.F Liu, S.H Bian, L.H Zhao, Explosive spalling and residual mechanical properties of fiber-toughened high-performance concrete subjected to high temperatures. Cement Concrete Res, 36, pp 723-7.

[28] P. Pliya, A.L Beaucour, A. Noumowé, A way to improve the behaviour of concrete at high temperature: addition of a cocktail of polypropylene and steel fibres. In: International fib congress and PCI annual convention/exhibition, Washington, 2010.

[29] B. Chen, J. Liu, (2004), Residual strength of hybrid-fiber reinforced high strength concrete after exposure to high temperature. Cement Concrete Res, 34:1065-9

[30] R. Demirbog, I. TurkmenK, M.B. Karakoc, Relationship between ultrasonic velocity and compressive strength for high-volume mineral-admixture concrete, Cement and Concrete Research 34, 2004, pp 2329 - 2336.

[31] Tharmaratnam, B.S. Tan, Attenuation of ultrasonic pulse in cement mortar, Cem. Concr. Res. 20, 1990, pp 335 345.

[32] D. Breysse, Nondestructive evaluation of concrete strength: An historical review and a new perspective by combining NDT methods, Construction and Building Materials 33, 2012, 139-163. 